\title{
BETWEEN-POPULATION VARIATION \\ IN PLANT PERFORMANCE TRAITS AND ELEMENTAL COMPOSITION OF COLCHICUM AUTUMNALE L. AND ITS RELATION TO EDAPHIC ENVIRONMENTS
}

\author{
LUCYNA MRÓZ \\ Department of Ecology, Biogeochemistry and Environmental Protection, Wrocław University \\ Kanonia 6/8, 50-328 Wrocław, Poland \\ e-mail: mrozl@biol.uni.wroc.pl
}

(Received: March 2, 2007. Accepted: October 31, 2007)

\begin{abstract}
Variation in vegetative and reproductive performance and leaf mineral composition among 25 populations of Colchicum autumnale (meadow saffron) from soils derived from six parent materials (limestone, marl, sandstone, greenstone, melaphyre and serpentine) in southwestern Poland has been investigated. The plant size (PS), total leaf area (TLA), leaf shape (LS), number of fruits per plant (NFP), number of seeds per plant (NFP), total weight seed per plant (TWSP) were estimated, and concentrations of seventeen elements (N, P, K, Ca, Mg, Na, S, Fe, $\mathrm{Mn}, \mathrm{Cu}, \mathrm{Zn}, \mathrm{Pb}, \mathrm{Cd}, \mathrm{Ni}, \mathrm{Co}, \mathrm{Cr}, \mathrm{Mo}$ ) were analyzed in leaf and soil samples. In soil samples, also soil pH, organic matter content and sand, silt and clay content were determined. All soils (except melaphyre soil) contained elevated levels of $\mathrm{Cr}$. Concentrations of soil $\mathrm{Ni}$ and $\mathrm{Zn}, \mathrm{Pb}, \mathrm{Cd}$ in serpentinite soil and polluted marl soils (respectively) were significantly higher than those of other examined soils. Meadow saffron leaves from all sites (except marl sites) contained elevated levels of $\mathrm{Cr}$, Co and $\mathrm{Ni}$. Statistical analysis, carried out with principal component analysis (PCA) revealed that a good correlation exists between the element content in leaves and plant performance traits and soil environment. The leaf Ca content and NFP were correlated and were much higher in populations from metal (except $\mathrm{Cr}$ ) and nutrient-poor marl soils than in those from metal (except $\mathrm{Ni}$ in serpentine soil) and nutrient moderate rich soils derived from melaphyre, greenstones, serpentinite, limestones and sandstones and in those from metal-rich and nutrient-poor polluted marl soils. Meadow saffron plants tended to take up higher amounts of $\mathrm{N}, \mathrm{P}, \mathrm{K}, \mathrm{Mn}, \mathrm{Cu}$ and $\mathrm{Na}$ and lower amounts of $\mathrm{S}$ and had much higher TLA in populations from sandstone soils than those in populations from serpentinite, melaphyre, greenstone, marl and limestone soils. The leaf Co, $\mathrm{Ni}, \mathrm{Cr}, \mathrm{Mg}$ concentrations were correlated and were much higher in populations from serpentinite, melaphyre, greenstone, polluted marl and limestone soils than those from marl and sandstone soils. The pattern of variation in NFP and TLA across the different soil types was the opposite of that for leaf $\mathrm{N}, \mathrm{Cu}, \mathrm{Na}, \mathrm{Ni}, \mathrm{Mg}$ and $\mathrm{S}$ concentrations. Redundancy analysis (RDA) enables identification of the soil variables that best explain the variance pattern of plant response. The variation explained by the soil variables (15 soil elements and soil $\mathrm{pH})$ was high (79\%). The forward selection of soil variables identified soil $\mathrm{Co}, \mathrm{Mo}, \mathrm{Ni}, \mathrm{Ca}$ and $\mathrm{Zn}$ concentrations as significantly influencing the ordination plant traits. The variation explained by these selected variables was $55 \%$. Thus the five soil variables appeared to be the main factors determining the pattern variation of vegetative, reproductive and nutrient traits of Colchicum autumnale.
\end{abstract}

KEY WORDS: vegetative and reproductive performance, mineral composition, parent material, soil properties, principal component analysis, redundancy analysis.

\section{INTRODUCTION}

Plants display variation in traits to a wide variety of ecological conditions. Individuals within a species may vary by orders of magnitude in size, growth rate, allocation to different organs, reproduction and chemical constituency (Callaway et al. 2003). The variation in plant traits induced by abiotic and biotic environment may allow the plants to adapt to different circumstances. A plant which has adapted to its environment can cope with a variation around so- me optima for a range of environmental conditions. Some species are more particular than others in their requirements (Falińska 2004).

Colchicum autumnale (Liliaceae) is a species with a wide geographical distribution in Europe, from Ireland and British Isles to the Sub Mediterranean area and from Central Europe to Western Ukraine (Tutin et al.1980). In the Balkan Peninsula it occurs in deep humus-rich soil on various substrates, in the southwestern part of the area generally on non-calcareous rocks such as schists, flysch, serpentines 
(Persson 1999). Serpentine soils represent a well known example of a stressful environment for plants (Brooks1987). These soils can offer an edaphic environment with abnormally high concentrations of $\mathrm{Ni}, \mathrm{Cr}, \mathrm{Co}, \mathrm{Mg}$ and $\mathrm{Fe}$, and a dearth of important nutrients $\mathrm{Ca}, \mathrm{K}, \mathrm{P}$ and N. Although some serpentine soils can be deep, most are shallow with a limited ability to retain moisture (Proctor 1999). Due to these environmental stresses, the growth forms and physiognomy of some of the plant species growing in these soils can be different from those of non-serpentine areas (Ghaderian et al. 2006). Most plants on serpentine soils show slightly elevated $\mathrm{Ni}, \mathrm{Co}$ and $\mathrm{Cr}$ concentrations in comparison with those in other soil types (Reeves et al.1999; Freitas et al.2004). The high concentration of heavy metals can act as potent agents of natural selection and where soil levels are high specialized, metal-tolerant plants may arise (Crawley 1997). In Poland, C. autumnale is found on serpentinite soil and other soils developed from noncalcareous and also calcareous substrates (Berdowski 1995; Kwiatkowski 1998; Piękoś-Mirkowa and Mirek 2003). Calcareous substrates such as limestone, marl and chalk wholly or in large part are composed of calcium carbonate. In Central Europe, limestone and chalk regions are exceptionally rich in species (Wohlgemuth and Gigon 2003). The ecological effects of calcium on plant performance appear to be indirect. Calcium modifies soil nutrient availability, and excess $\mathrm{Ca}$ can bring about deficiencies of $\mathrm{P}, \mathrm{Mg}, \mathrm{Fe}$ or trace elements. Calcium modifies the relative competitive ability of plants for different nutrients. Calcareous soil tends to be porous and to have low soil water content, with the consequence that temperatures are relatively high and aeration is good (Crawley 1997). The occurrence of C. autumnale in contrasting soils (calcareous and non-calcareous) provided an opportunity to investigate both the pattern response of this species to edaphic environments, and geological substrates that determine it. The difference in soil nutrient availability may have implications for variation of plant performance traits (vegetative as well as reproductive), with changes in foliar nutrient concentrations. Although morphology, physiology and biochemistry of $C$. autumnale have attracted a lot attention (Persson 1993,1999; Poutaraud and Girardin 2003, 2005, 2006; Franková et al. 2003, 2004; Franková et al. 2004), the ecological variation of vegetative as well as reproductive performance is still insufficiently understood. Only the influence of the soil characteristics has been studied, showing that reproductive success correlated positively with soil $\mathrm{pH}$ and $\mathrm{Ca}, \mathrm{Mg}$ and $\mathrm{Cu}$ concentrations and negatively with $\mathrm{N}$ and $\mathrm{K}$ concentrations (Mróz 2006) and plant performance decreased with $\mathrm{N}$ fertilization (Rutkowska 1984). This suggests that direct toxicity of high levels of $\mathrm{N}$ and $\mathrm{K}$ might play a decisive role in determining the performance of this species. The variation in the ability to absorb elements from various soil types has not yet been studied. It would be desirable, therefore, to gain greater knowledge about the pattern of variation between site characteristics, vegetative and reproductive traits and mineral element composition. Variation in natural populations may provide the basis for artificial breeding programmes.

The aim of this study was to determine the variation in vegetative and reproductive characteristics and mineral element composition among populations of $C$. autumnale from the soils derived from various parent rock such as limestones, marls, sandstones, greenstones, melaphyres and serpentines and how they are related to edaphic factors.

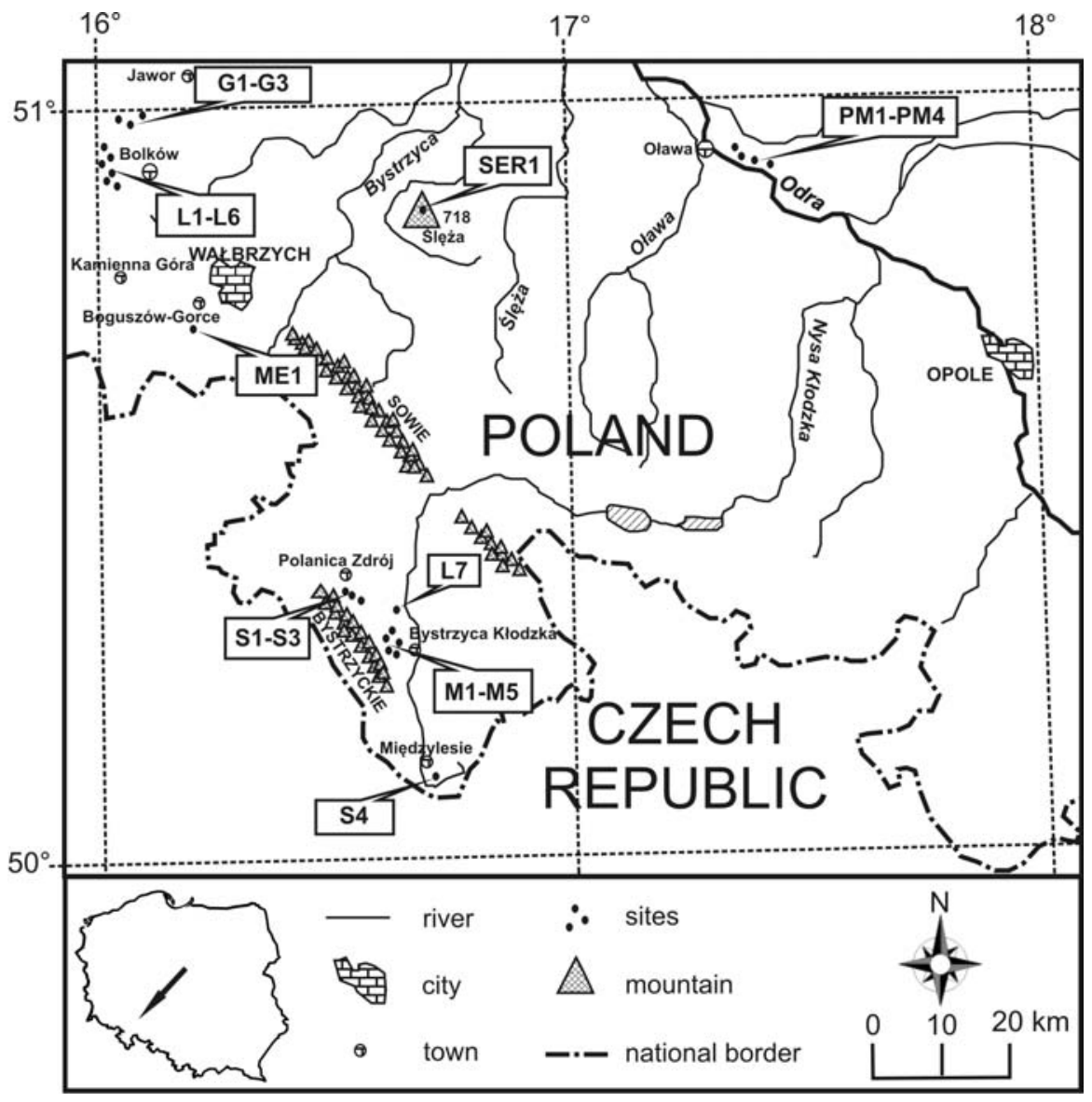

Fig. 1. Map of sites of Colchicum autumnale populations in southwestern Poland. For site abbreviations see Table 1. 
The following specific questions were addressed:

1 . How broad is the variation in vegetative as well as reproductive characteristics and leaf mineral composition?

2. Are those plant parameters related to each other?

3. Can this variation in plant parameters be related to specific soil properties?

4. What is the general relationship between plant parameters and soil properties?

\section{MATERIAL AND METHODS}

\section{Study species and sampling sites}

Colchicum autumnale (meadow saffron) is a herbaceous perennial cormous geophyte. The corm (upper part) is located between 10 and $20 \mathrm{~cm}$ into the soil, the fine white roots grow deeply until about $80 \mathrm{~cm}$ from the lower part of the corm (Poutaraud and Girardin 2005). The root system appears first at the end of September (in the middle of flowering) and remains active up till May, when the programmed senescence of the above-ground part and the final physical destruction of the mother corm take place (Franková et.al 2004). Meadow saffron has a rather unusual biology. Flowering takes place in September, fruiting in June (Godet 1987). It is an important medicinal plant, in many countries, because it is a source of alkaloids exploited in the pharmaceutical industry and in plant biotechnology
(Raskin et al. 2002). The plant is not yet domesticated. It is difficult to cultivate. The percentage of seed germination is low. The time span between germination and first flowering takes a minimum of four years (Poutaraud and Girardin 2006)

Twenty five populations of $C$. autumnale (Fig. 1, Table 1) from soils developed on various parent materials were selected in the southwestern part of the Poland. These populations represent a large fraction of the populations existing in the area. Six populations were situated in the Kaczawa Mts on soils developed on limestones (L1-L6 hereafter); three populations in the Kaczawa Foothills on greenstone soils (G1-G3); one population in the Kamienne Mts on melaphire soil (ME1); one population in the Krowiarki on 1imestone soil (L7); nine populations in the Bystrzyckie Mts on sandstone and marl soils (S1-S4 and M1-M5 respectively); one population in the Ślęża Massif on serpentine soil (SER1) and four populations in the Wrocław Ice-marginal Valley on polluted marl soils (PM1-PM4). All sites with the exception PM1-PM4 can be considered sites with minimal pollution. The PM1-PM4 sites were located 5 and 7 $\mathrm{km}$ from the zinc-lead smelter, where soils are contaminated with heavy metal (Mróz 2002).

For each of the study sites, longitude, latitude and altitude were obtained from maps. The inclination and exposure of the sites were recorded in the field. Data for mean annual precipitation and temperature were obtained from the In-

TABLE 1. The location and characteristics of sites of the 25 Colchicum autumnale populations in southwestern Poland.

\begin{tabular}{|c|c|c|c|c|c|c|c|}
\hline $\begin{array}{l}\text { Location, } \\
\text { geological substrate }\end{array}$ & $\begin{array}{l}\text { Site } \\
\text { abbreviation }\end{array}$ & $\begin{array}{l}\text { Coordinates } \\
\text { Latitude (N), Longitude (E) }\end{array}$ & $\begin{array}{l}\text { Altitude } \\
\text { (m a.s.l) }\end{array}$ & $\begin{array}{l}\text { Inclination }\left(^{\circ}\right) \text {, } \\
\text { exposure }\end{array}$ & $\begin{array}{l}\text { Mean annual } \\
\text { precipitation } \\
\quad(\mathrm{mm})\end{array}$ & $\begin{array}{c}\text { Mean annual } \\
\text { temperature } \\
\left({ }^{\circ} \mathrm{C}\right)\end{array}$ & $\begin{array}{l}\text { Habitat or } \\
\text { vegetation type }\end{array}$ \\
\hline $\begin{array}{l}\text { Kaczawa } \\
\text { Mountains, limestone }\end{array}$ & $\begin{array}{l}\text { L1 } \\
\text { L2 } \\
\text { L3 } \\
\text { L4 } \\
\text { L5 } \\
\text { L6 }\end{array}$ & $\begin{array}{l}50^{\circ} 56^{\prime} 39^{\prime},, 16^{\circ} 03^{\prime} 04^{\prime}, \\
50^{\circ} 56^{\prime} 19^{\prime},, 16^{\circ} 033^{\prime} 14^{\prime}, \\
50^{\circ} 56^{\prime} 41^{\prime},, 16^{\circ} 02^{\prime} 34^{\prime}, \\
50^{\circ} 56^{\prime} 21^{\prime},, 16^{\circ} 02^{\prime} 14^{\prime}, \\
50^{\circ} 56^{\prime} 29^{\prime},, 16^{\circ} 03^{\prime} 08^{\prime}, \\
50^{\circ} 57^{\prime} 23^{\prime},, 16^{\circ} 02^{\prime} 26^{\prime}\end{array}$ & $\begin{array}{l}350 \\
350 \\
400 \\
350 \\
350 \\
400\end{array}$ & $\begin{array}{l}5.6 / \mathrm{NE} \\
5.6 / \mathrm{NE} \\
3.2 / \mathrm{SW} \\
3 / \mathrm{SW} \\
3 / \mathrm{SW} \\
10 / \mathrm{W}\end{array}$ & 874 & 7.4 & $\begin{array}{l}\text { road verge } \\
\text { meadow } \\
\text { meadow } \\
\text { meadow } \\
\text { meadow } \\
\text { road verge }\end{array}$ \\
\hline $\begin{array}{l}\text { Kaczawa } \\
\text { Foothills, greenstone }\end{array}$ & $\begin{array}{l}\text { G1 } \\
\text { G2 } \\
\text { G3 }\end{array}$ & $\begin{array}{l}50^{\circ} 59^{\prime} 37^{\prime},, 16^{\circ} 04^{\prime} 28^{\prime}, \\
50^{\circ} 59^{\prime} 35^{\prime}, \\
50^{\circ} 59^{\prime} 54^{\prime}, ', 16^{\circ} 06^{\prime} 32^{\prime},\end{array}$ & $\begin{array}{l}320 \\
320 \\
320\end{array}$ & $\begin{array}{l}2 / \mathrm{SE} \\
3 / \mathrm{NW} \\
3.2 / \mathrm{NW}\end{array}$ & 758 & 9.1 & $\begin{array}{l}\text { meadow } \\
\text { meadow } \\
\text { meadow }\end{array}$ \\
\hline $\begin{array}{l}\text { Kamienne } \\
\text { Mountains, melaphyre }\end{array}$ & ME1 & $50^{\circ} 42^{\prime} 37^{\prime \prime}, 16^{\circ} 08^{\prime} 38^{\prime \prime}$ & 470 & $2 / \mathrm{E}$ & 851 & 6.3 & road verge \\
\hline Krowiarki, limestone & L7 & $50^{\circ} 21^{\prime} 10^{\prime \prime}, 16^{\circ} 39^{\prime} 33^{\prime}$, & 460 & $2.3 / \mathrm{SW}$ & 758 & 7.6 & road verge \\
\hline $\begin{array}{l}\text { Bystrzyckie Mountains, } \\
\text { sandstone and marl }\end{array}$ & $\begin{array}{l}\text { S1 } \\
\text { S2 } \\
\text { S3 } \\
\text { S4 } \\
\text { M1 } \\
\text { M2 } \\
\text { M3 } \\
\text { M4 } \\
\text { M5 }\end{array}$ & 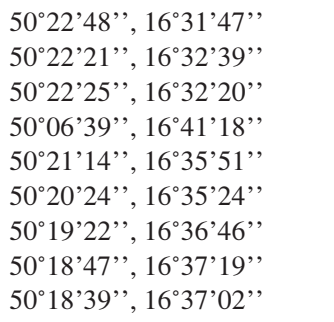 & $\begin{array}{l}410 \\
410 \\
410 \\
480 \\
350 \\
350 \\
370 \\
360 \\
380\end{array}$ & $\begin{array}{l}1 / \mathrm{NE} \\
1 / \mathrm{NE} \\
1 / \mathrm{NE} \\
1.5 / \mathrm{E} \\
0.5 / \mathrm{E} \\
0.5 / \mathrm{E} \\
0.5 / \mathrm{E} \\
1 / \mathrm{E} \\
1 / \mathrm{E}\end{array}$ & 836 & 7.6 & $\begin{array}{l}\text { meadow } \\
\text { meadow } \\
\text { road verge } \\
\text { meadow } \\
\text { meadow } \\
\text { meadow } \\
\text { meadow } \\
\text { meadow } \\
\text { meadow }\end{array}$ \\
\hline Ślęża Massif, serpentinite & SER1 & $50^{\circ} 50^{\prime} 52^{\prime} \prime, 16^{\circ} 45^{\prime} 08^{\prime \prime}$ & 290 & $7 / \mathrm{NE}$ & 745 & 8.8 & shrub \\
\hline $\begin{array}{l}\text { Wrocław } \\
\text { Ice-marginal Valley, } \\
\text { marl (polluted soils) }\end{array}$ & $\begin{array}{l}\text { PM1 } \\
\text { PM2 } \\
\text { PM3 } \\
\text { PM4 }\end{array}$ & $\begin{array}{l}50^{\circ} 58^{\prime} 26^{\prime},, 17^{\circ} 18^{\prime} 32^{\prime}, \\
50^{\circ} 58^{\prime} 50^{\prime},, 17^{\circ} 18^{\prime} 26^{\prime}, \\
50^{\circ} 56^{\prime} 31^{\prime},, 17^{\circ} 20^{\prime} 55^{\prime}, \\
50^{\circ} 55^{\prime} 29^{\prime},, 17^{\circ} 22^{\prime} 11^{\prime},\end{array}$ & $\begin{array}{l}130 \\
130 \\
130 \\
130\end{array}$ & $\begin{array}{l}0 / \mathrm{NE} \\
0 / \mathrm{NE} \\
0 / \mathrm{E} \\
0 / \mathrm{SE}\end{array}$ & 619 & 8.9 & $\begin{array}{l}\text { shrub } \\
\text { meadow } \\
\text { meadow } \\
\text { riparian } \\
\text { floodplain }\end{array}$ \\
\hline
\end{tabular}


stitute of Meteorology and Water Management, Wrocław. Information regarding geological conditions at the sites was taken from the maps created by the Polish Geological Institute, Wrocław.

\section{Plant samples}

In 2001, at the end of June, during full fruiting, ten plots $(1 \times 1 \mathrm{~m})$ in each population were randomly selected. The place of every plot was marked by coordinates chosen from tables of random numbers (Zar 1999). In each plot reproductive plants were counted. Vegetative plants were excluded from the experiment. The following traits of the reproductive plants were assessed: the number of fruits, the number of leaves, the length and width of each leaf. A total of 1271 plants were studied. Plant size was estimated as the length of the longest leaf times the number of leaves. Total leaf area was estimated as by summing up the product $q \times$ (length $\times$ width) for all leaves of a plant. The leaves are geometrically similar and therefore $q$ is a constant, which in this case was set equal to 0.5 (Kindlmann and Balounová 1999). Total leaf area was used as an estimate of vegetative growth. The ratio (leaf length)/(leaf width) was calculated to quantify the shape of the leaf.

Afterwards, in each plot, one mature unopened fruit and one undamaged leaf were collected at random. Seeds were counted and weighed after draying to a constant mass at $70^{\circ} \mathrm{C}$. The number of seeds per plant was calculated as the average number of seeds per fruit multiplied by the total number of fruits per plant. Mean individual seed mass was calculated as the total seed mass from ten fruits divided by the total number of seeds. Total seed weight per plant was calculated as the total number of seeds per plant multiplied by the mean seed mass. Leaves were dried in paper bags at $60^{\circ} \mathrm{C}$ for $48 \mathrm{~h}$ and immediately ground in a mill. Powdered leaf tissue was ashed in a muffle furnace at $450^{\circ} \mathrm{C}$ for $8 \mathrm{~h}$. The resulting ash was dissolved in $20 \% \mathrm{HCl}$ and heated to boiling point on a hot plate to extract leaf total macroelements. Such prepared extract was used for analyses of $\mathrm{P}$ by molybdate blue method, of $\mathrm{K}, \mathrm{Ca}$ and $\mathrm{Na}$ by flame atomic emission spectrophotometry (FAES; PFP 7 Jenway) and of $\mathrm{Mg}$ by flame atomic absorption spectrophotometry (FAAS; Perkin-Elmer AAS 3300). Plant total N content was determined by the Kjeldahl's method and total S content was determined by Carbo Erba NA-1500 Analyzer. The microelements were extracted using microwave digestion with $\mathrm{HNO}_{3}$ (conc.) and $\mathrm{HCl}$ (conc.) in Teflon vessels. Total $\mathrm{Fe}, \mathrm{Mn}, \mathrm{Cu}$ and $\mathrm{Zn}$ levels were measured by flame atomic absorption spectrophometry (FAAS; Perkin-Elmer AAS 3300), Pb, Cd, $\mathrm{Ni}, \mathrm{Co}, \mathrm{Cr}$ and Mo levels were measured by electrothermal atomic absorption spectrophotomery (ETAAS; Perkin-Elmer AAS 3300). All microelements were measured against standards and blanks prepared in concentrated nitric and hydrochloric acid. All analyses were done in duplicate. All results for the plants were calculated on a dry weight basis.

\section{Soil samples}

For all locations, where plant parameters were determined in $C$. autumnale, ten soil samples $(30 \mathrm{~cm}$-deep cores) were taken in the neighbourhood of the sampled plants. The samples were air-dried, thoroughly mixed and sieved ( $2 \mathrm{~mm}$ ). The available nutrients $\mathrm{P}, \mathrm{K}, \mathrm{Ca}, \mathrm{Mg}$ and $\mathrm{Na}$ were extracted using an acetic acid ( $\mathrm{pH}$ 3.1) solution. Phosphorus was measured colourmetrically with vanadium molyb- date, $\mathrm{K}, \mathrm{Ca}, \mathrm{Na}$ and $\mathrm{Mg}$ were measured with FAES and FAAS, respectively. Soil total $\mathrm{N}, \mathrm{S}, \mathrm{Fe}, \mathrm{Mn}, \mathrm{Cu}, \mathrm{Zn}, \mathrm{Pb}$, $\mathrm{Cd}, \mathrm{Ni}, \mathrm{Co}, \mathrm{Cr}$ and Mo content was analysed using the same procedures as described for the plant samples. The $\mathrm{pH}$ was measured by a $\mathrm{pH}$ meter $(\mathrm{CP}-104)$ in a $1 \mathrm{M} \mathrm{KCl}$ extract of the soil: $\mathrm{KCl}$ ratio of $1: 2.5$. Sand, silt and clay content was determined by particle analysis (Sysmex FPIA-3000). The organic material content (OM) was estimated as the difference in mass of the same soil sample before and after burning it in a furnace oven at $600^{\circ} \mathrm{C}$ for $1 \mathrm{~h}$. $\mathrm{OM}$ content was expressed as a percent of dry mass.

\section{Data analysis}

Inter-site variation in soil properties and plant parameters was quantified by a coefficient of variation (CV), defined as: $\mathrm{CV}=\mathrm{SD} /$ mean multiplied by $100 \%$. The SD in the formula was calculated with the mean soil and plant variables of individual sites. The sites were characterized according to their soil variables by means of a principal component analysis (PCA). A preliminary PCA was carried out to investigate the relationship between soil characteristics (Table 2). The $\mathrm{pH}$ and sand, silt, clay and OM content were considered as supplementary variables (Legendre and Legendre 1998). The preliminary PCA showed that $\mathrm{Na}$ and $\mathrm{S}$ made variance drop below $1 \%$. Based on the results of this analysis, redundant variables $(\mathrm{Na}$ and $\mathrm{S}$ ) were eliminated and analysis was repeated on a subset of all the soil variables. The PCA analysis was also executed with the plant parameters (Table 2). Soil and plant variables having a loading greater than 0.6 in a factor were considered as related to that factor. The results of the PCA analysis were visualized by means of diagrams obtained by overlapping scores and loadings plots for PC1 vs PC2 and PC2 vs PC3 (Legendre and Legendre 1998). Scatter plots of the first two axes, and the second and the third axes, derived from PCA with a subset of the soil variables of 25 sites, clearly represented all distinguished groups of sites. Afterwards a oneway ANOVA (Zar 1999) was used to determine the significance of the differences within the soil characteristics between distinct groups distinguished in PCA. All data were analysed using STATISTICA 7.1 (StatSoft Inc. 2005).

Redundancy analysis (RDA) was applied to study the simultaneous relationships between plant parameters and soil characteristics. RDA is an ordination method which summarises overall variation in "species data" (plant parameters in this case) in a few ordination axes which are a linear combination of the measured environmental variables (soil characteristics in this case) (Lepš and Šmilauer 2005). Twenty three plant parameters were included, six related to plant performance traits and seventeen related to chemical plant composition (Table 2). Variables were transformed by centring and standardizing by "species", because plant parameters were measured in different units. Sixteen soil variables (soil $\mathrm{pH}$ and all soil elements except $\mathrm{Na}$ and $\mathrm{S}$ ) were considered (Table 2). Unconstrained Monte Carlo permutation tests were used to assess the statistical significance of the association between plant and soil variables. In all cases 9999 permutations were utilized (Lepš and Šmilauer 2005). First, the significance of the whole ordination, and of the first ordination axis, was assessed. Second, a forward stepwise method was used to choose the soil variables significantly affecting the ordination. The RDA results were visualized by the means of a diagram which re- 
TABLE 2. Mean and standard deviation (in parentheses except for the ME1, L7 and SER1 location where $\mathrm{n}=1$ for all variables) values for the 22 soil variables and 23 plant variables at the sites of the 25 study populations of Colchicum autumnale in southwestern Poland. For site abbreviations see Table 1.

\begin{tabular}{|c|c|c|c|c|c|c|c|c|c|}
\hline & \multicolumn{8}{|c|}{ Site } & \multirow{2}{*}{$\mathrm{CV}^{\mathrm{a}}$} \\
\hline & $\begin{array}{c}\text { L1-L6 } \\
n=6\end{array}$ & $\begin{array}{c}\text { G1-G3 } \\
n=3\end{array}$ & $\begin{array}{c}\text { ME } 1 \\
n=1\end{array}$ & $\begin{array}{c}\mathrm{L} 7 \\
\mathrm{n}=1\end{array}$ & $\begin{array}{c}\text { S1-S4 } \\
n=4\end{array}$ & $\begin{array}{c}\text { M1-M5 } \\
n=5\end{array}$ & $\begin{array}{c}\text { SER1 } \\
\mathrm{n}=1\end{array}$ & $\begin{array}{c}\text { PM1-PM4 } \\
n=4\end{array}$ & \\
\hline \multicolumn{10}{|l|}{ Soil variables: abbrev. } \\
\hline $\mathrm{pH}: \mathrm{pH}$ & $6.4(0.1)$ & $4.7(0.4)$ & 5.8 & 6.4 & $5.4(1.0)$ & $5.4(0.6)$ & 5.1 & $4.8(0.2)$ & 14.7 \\
\hline Nitrogen $(\mathrm{g} / \mathrm{kg}): \mathrm{N}$ & $3.06(0.33)$ & $3.13(0.73)$ & 3.65 & 3.45 & $3.81(0.47)$ & $3.01(0.42)$ & 3.12 & $3.04(0.48)$ & 17.0 \\
\hline Phosphorus (mg/kg): P & $43.6(6.6)$ & $29.1(5.2)$ & 57.8 & 38.9 & $30.1(5.7)$ & $12.3(4.5)$ & 77.1 & $28.5(10.5)$ & 43.2 \\
\hline Potassium (mg/kg): K & $32.8(4.1)$ & $22.3(17.2)$ & 103 & 54.7 & $48.9(26.9)$ & $65(12.1)$ & 19.1 & $25.5(1.1)$ & 56.5 \\
\hline Calcium (g/kg): Ca & $3.62(0.35)$ & $1.06(0.24)$ & 1.60 & 4.66 & $1.34(0.43)$ & $0.72(0.16)$ & 0.31 & $0.67(0.23)$ & 79.6 \\
\hline Magnesium (mg/kg): $\mathrm{Mg}$ & $562(143)$ & $150(24.1)$ & 29.8 & 377 & $46.7(16.3)$ & $76.6(19.5)$ & 144 & $77.0(5.6)$ & 106 \\
\hline Sodium $(\mathrm{mg} / \mathrm{kg}): \mathrm{Na}$ & $11.4(1.5)$ & $25.0(5.4)$ & 22.5 & 13.3 & $31.1(12.1)$ & $22.6(7.3)$ & 19.6 & $17.8(2.7)$ & 43.4 \\
\hline Sulfur (mg/kg): S & $380(36.1)$ & $298(46.0)$ & 497 & 419 & $325(65.3)$ & $431(41.1)$ & 473 & $387(27.1)$ & 17.0 \\
\hline Iron $(\mathrm{g} / \mathrm{kg}): \mathrm{Fe}$ & $20.1(2.2)$ & $21.5(2.2)$ & 31.1 & 17.3 & $24.7(2.3)$ & $16.6(2.9)$ & 23.7 & $19.7(1.8)$ & 19.3 \\
\hline Manganese: $(\mathrm{g} / \mathrm{kg}):$ Mn & $0.76(0.12)$ & $0.72(0.12)$ & 0.79 & 0.48 & $0.85(0.36)$ & $0.31(0.08)$ & 1.24 & $0.58(0.12)$ & 41.5 \\
\hline Copper (mg/kg): $\mathrm{Cu}$ & $20.9(3.1)$ & $34.8(11.8)$ & 23.2 & 15.6 & $19.9(2)$ & $15.9(3.7)$ & 16.3 & $33.2(3.6)$ & 36.2 \\
\hline Zinc (mg/kg): Zn & $115(26.3)$ & $70.5(7.1)$ & 76.6 & 65.2 & $89.2(3)$ & $62(15.2)$ & 62.4 & $265(60.2)$ & 66.2 \\
\hline Lead $(\mathrm{mg} / \mathrm{kg}): \mathrm{Pb}$ & $21.5(6.0)$ & $14.8(6.9)$ & 12.4 & 11.6 & $16.3(2.9)$ & $11.8(0.9)$ & 12.2 & $37.4(5.4)$ & 50.2 \\
\hline Cadmium (mg/kg): Cd & $0.63(0.05)$ & $0.67(0.3)$ & 0.20 & 0.10 & $0.58(0.24)$ & $0.19(0.07)$ & 0.8 & $1.26(0.3)$ & 65.8 \\
\hline Nickel (mg/kg): Ni & $28.3(5.2)$ & $64.7(23.2)$ & 25.1 & 24.2 & $39.3(3.4)$ & $23.9(3.5)$ & 294 & $31.0(2.1)$ & 121 \\
\hline Cobalt $(\mathrm{mg} / \mathrm{kg}):$ Co & $11.7(0.9)$ & $10.8(0.5)$ & 13.7 & 6.1 & $11.8(0.3)$ & $5(1.1)$ & 7.4 & $10.3(0.8)$ & 30.0 \\
\hline Chromium (mg/kg): Cr & $103(14.4)$ & $137(24.2)$ & 30.2 & 88.2 & $115(6.8)$ & $93.8(5.2)$ & 159 & $106(7.5)$ & 23.9 \\
\hline Molybdenum (mg/kg): Mo & $0.78(0.19)$ & $0.36(0.07)$ & 0.55 & 0.85 & $1.3(0.3)$ & $0.55(0.09)$ & 0.59 & $0.54(0.15)$ & 44.4 \\
\hline Sand $(\%):$ Sand & $30.5(13.1)$ & $28.0(10.4)$ & 15.2 & 29.7 & $35.7(2.9)$ & $23.7(4.5)$ & 28.3 & $39.1(5.9)$ & 31.4 \\
\hline Silt (\%): Silt & $62.8(13.6)$ & $64.3(6.3)$ & 78.7 & 64.5 & $57(2.1)$ & $66.9(2.9)$ & 67.7 & $55.4(5.3)$ & 14.1 \\
\hline Clay (\%): Clay & $6.7(2.9)$ & $7.7(4.2)$ & 6.1 & 5.8 & $7.3(0.9)$ & $9.3(2.7)$ & 4.0 & $5.4(0.7)$ & 36.6 \\
\hline Organic matter $(\%)$ : OM & $10.4(2.1)$ & $10.7(0.7)$ & 11.8 & 7.1 & $14.2(2.61)$ & $10.1(1.2)$ & 19.2 & $10.4(1)$ & 24.0 \\
\hline \multicolumn{10}{|l|}{ Plant variables: abbrev. } \\
\hline Number fruits per plant: NFP & $1.65(0.21)$ & $1.51(0.05)$ & 1.12 & 1.54 & $1.4(0.21)$ & $2.1(0.16)$ & 1.0 & $1.95(0.25)$ & 20.8 \\
\hline Number seeds per plant: NSP & $122(17)$ & $114(11)$ & 82 & 115 & $103(21)$ & $114(21)$ & 86 & $119(16)$ & 16.4 \\
\hline Total weight seed per plant (g): TWSP & $0.56(0.12)$ & $0.50(0.05)$ & 0.41 & 0.59 & $0.50(0.13)$ & $0.51(0.13)$ & 0.28 & $0.54(0.08)$ & 20.5 \\
\hline Plant size $(\mathrm{cm}):$ PS & $110.2(7.8)$ & $92.3(13.4)$ & 91.9 & 70.7 & $127.1(24.5)$ & $98.1(22.6)$ & 114.5 & $99.7(11.3)$ & 18.9 \\
\hline Total leaf area $\left(\mathrm{cm}^{2}\right)$ : TLA & $184(17.4)$ & $136(25.5)$ & 132 & 104 & $229(70.1)$ & $196(70.7)$ & 163 & $168(24.1)$ & 29.0 \\
\hline Leaf shape: LS & $9.5(1.1)$ & $9.4(1.3)$ & 10.1 & 6.8 & $9.8(0.3)$ & $6.7(0.5)$ & 15.3 & $8.41 .0)$ & 21.8 \\
\hline Nitrogen $(\mathrm{g} / \mathrm{kg}): \mathrm{N}$ & 20.7 (2.9) & $20.7(1.5)$ & 16.1 & 16.6 & $26.1(1.9)$ & $14.9(1.1)$ & 16.7 & $17.4(2.4)$ & 21.6 \\
\hline Phosphorus (g/kg): P & $2.21(0.6)$ & $2.77(0.11)$ & 1.49 & 2.41 & $3.78(0.9)$ & $1.50(0.5)$ & 1.15 & $2.15(0.9)$ & 42.2 \\
\hline Potassium (g/kg): K & $16.4(2.6)$ & $11.2(5.7)$ & 16.2 & 12.2 & $36.3(5.9)$ & $14(3.1)$ & 12.9 & $12.1(1.3)$ & 52.4 \\
\hline Calcium (g/kg): Ca & $4.04(0.74)$ & $3.87(0.72)$ & 6.02 & 4.63 & $3.5(0.17)$ & $9.45(0.97)$ & 5.01 & $7.07(2.20)$ & 43.9 \\
\hline Magnesium (g/kg): Mg & $3.85(0.56)$ & $4.06(1.11)$ & 3.85 & 3.12 & $2.96(0.29)$ & $2.02(0.27)$ & 4.65 & $3.29(0.62)$ & 27.7 \\
\hline Sodium $(\mathrm{mg} / \mathrm{kg}): \mathrm{Na}$ & $233(42.8)$ & 255 (114) & 304 & 164 & $334(67)$ & $151(74)$ & 262 & $254(37.8)$ & 34.3 \\
\hline Sulfur $(\mathrm{g} / \mathrm{kg}): \mathrm{S}$ & $1.14(0.17)$ & $1.10(0.29)$ & 1.59 & 1.22 & $0.25(0.18)$ & $0.91(0.41)$ & 0.65 & $1.02(0.18)$ & 39.6 \\
\hline Iron $(\mathrm{mg} / \mathrm{kg}): \mathrm{Fe}$ & $192(58.3)$ & $147(39.3)$ & 180 & 488 & $206(27)$ & $79(23)$ & 60 & $168(43.2)$ & 53.4 \\
\hline Manganese $(\mathrm{mg} / \mathrm{kg}): \mathrm{Mn}$ & $25.7(4.0)$ & $24.1(6.1)$ & 19.8 & 43.9 & $43.2(7.8)$ & $18.6(5.7)$ & 10.9 & $27.2(3.7)$ & 38.1 \\
\hline Copper (mg/kg): Cu & $7.3(1.3)$ & $6.7(0.1)$ & 6.6 & 8.2 & $20.3(0.4)$ & $5.02(0.8)$ & 6.8 & $6.3(1.4)$ & 61.0 \\
\hline Zinc (mg/kg): Zn & $39.4(5.2)$ & $65.1(11.1)$ & 25.3 & 52.1 & $25.8(2.2)$ & $32.4(8.9)$ & 40.9 & $87.739 .8)$ & 56.8 \\
\hline Lead $(\mathrm{mg} / \mathrm{kg}): \mathrm{Pb}$ & $0.52(0.05)$ & $0.45(0.05)$ & 0.86 & 0.95 & $0.69(0.08)$ & $0.79(0.16)$ & 0.32 & $0.72(0.08)$ & 27.3 \\
\hline Cadmium (mg/kg): Cd & $0.14(0.04)$ & $0.18(0.03)$ & 0.12 & 0.18 & $0.68(0.05)$ & $0.18(0.04)$ & 0.20 & $0.62(0.27)$ & 78.3 \\
\hline Nickel (mg/kg): Ni & $2.49(0.44)$ & $2.84(0.42)$ & 2.42 & 2.72 & $2.05(0.4)$ & $1.14(0.07)$ & 2.75 & $2.33(0.16)$ & 29.7 \\
\hline Cobalt (mg/kg): Co & $2.12(0.30)$ & $1.36(0.61)$ & 2.31 & 2.07 & $1.44(0.18)$ & $0.54(0.09)$ & 1.23 & $2.01(0.32)$ & 42.8 \\
\hline Chromium (mg/kg): Cr & $2.81(0.12)$ & $2.52(0.25)$ & 3.10 & 3.78 & $2.58(0.46)$ & $1.09(0.22)$ & 2.53 & $3.12(0.51)$ & 32.6 \\
\hline Molybdenum (mg/kg): Mo & $0.33(0.09)$ & $0.16(0.13)$ & 0.36 & 0.52 & $0.25(0.06)$ & $0.24(0.11)$ & 0.24 & $0.15(0.12)$ & 49.3 \\
\hline
\end{tabular}

${ }^{\text {a }}$ Coefficient of variation (in $\left.\%\right)$.

presents the overall relationship between soil characteristics and plant parameters and main elements determining plant parameters. The analysis was undertaken using CANOCO 4.0 (ter Braak and Šmilauer 2002).

\section{RESULTS}

\section{Edaphically characterization of the sites}

There was a broad inter-site variation in all the soil variables measured (Table 2). PCA analysis extracted three fac- tors, explaining $69 \%$ of the variation in the data set. The first factor, accounting for $29 \%$ of the variation was mainly related to $\mathrm{Pb}, \mathrm{Zn}, \mathrm{Cu}, \mathrm{Cd}$, and $\mathrm{Co}$ in the positive side and $\mathrm{K}$ in the negative side (Fig. 2). The second factor, explaining $23 \%$ of the variation was mainly related to $\mathrm{N}, \mathrm{P}, \mathrm{Mn}$, $\mathrm{Fe}$ in the positive side. Mo also had a positive loading (0.60) in the second factor (Fig. 2). The third factor, accounting for $17 \%$ was mainly related to $\mathrm{Ca}, \mathrm{Mg}$ and $\mathrm{pH}$ in the negative side and $\mathrm{Ni}$ in the positive side. $\mathrm{Cr}$ also had a positive loading (0.58) in the third factor (Fig. 2). 


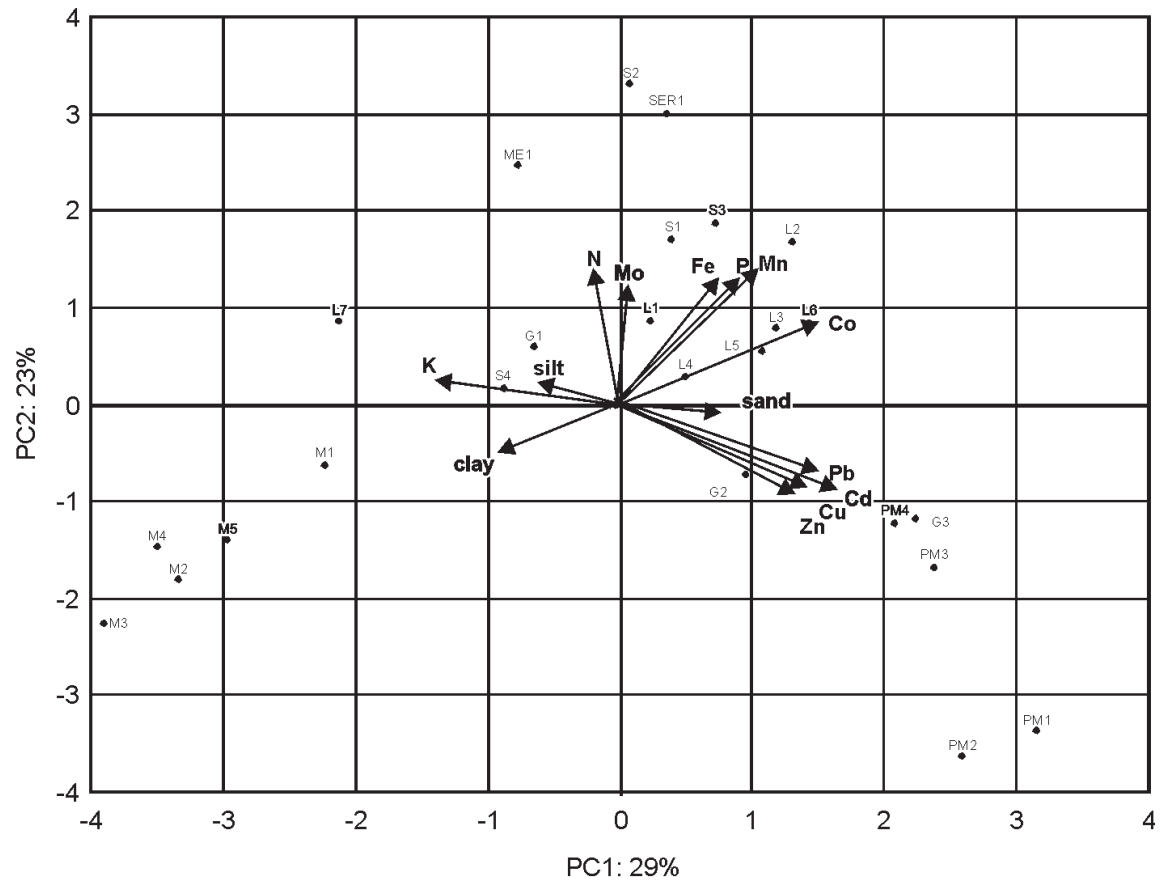

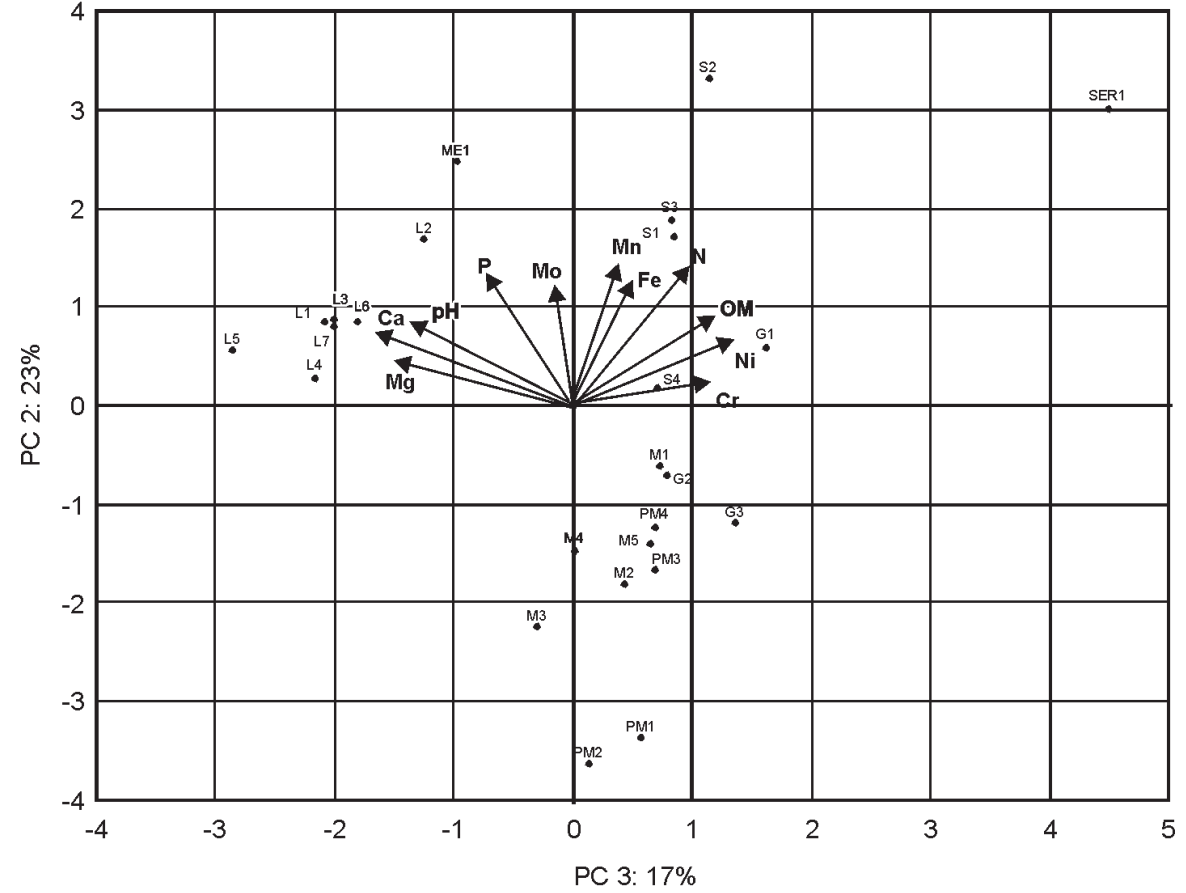

Fig. 2. Ordination of the 25 sites (dots) along three axes extracted by a PCA analysis based on twenty soil variables measured at each site. [Arrows indicate the strength and direction of the relationship between each variable and each axis. Relationship with the axis increases with the length of the arrow and decreases with increasing angle respect to the axis. Relationships between variables can be inferred from the angle between arrows (maximum for parallel arrows; minimum for perpendicular arrows). The soil descriptor scores were multiplied by 2 before plotting]. For abbreviations see Tables 1-2.
These factors can be interpreted as gradients in heavy metal level soil, richness in soil nutrients and soil $\mathrm{pH}$. Overall, four groups of sites could be distinguished (Fig. 2): (a) PM1-PM4 and G2-G3 sites (polluted marl soils and greenstone soils) had positive and negative values for the first and second factor respectively (characterized by a high content of heavy metals, nutrient-poor soils, acid $\mathrm{pH}$ ), (b) M1-M5 sites (marl soils) with negative values for the first and second factor (low content of metals, poor soils and acid to slightly acid pH), (c) L1-L7 and ME1sites (limestone and melaphyre soils respectively) had positive and negative values for the second and third factor respectively (intermediate content of metals, moderate rich soils, slightly acid pH), (d) S1-S4, G1 and SER1 sites (sandstone, gre- enstone and serpentinite soils respectively) with positive values for the second and third factor (intermediate content of metals, absolutely moderate nutrient content but nutrient levels in S2 and SER1 relatively higher than those of the other sites, acid to slightly acid $\mathrm{pH}$ ). Moreover SER1 site (serpentinite soil) is characterized by its highest content of $\mathrm{Ni}$; this site has unique features that keep it isolated from all other sites (Fig. 2). The relevance of transition metals and nutrients in soil $\mathrm{pH}$ discriminating between the four pointed out groups has been confirmed with one-way ANOVA. There was only no significant difference between the concentrations of $\mathrm{Ni}$ in the soil in relation to the four groups of sites (Table 3 ). 
TABLE 3. Results of one- way ANOVA of soil characteristics for four site types distinguished in PCA (see text). F-ratios $\left(\mathrm{F}_{0.05}=3.1, \mathrm{df}=3\right.$, df $=21$ ) and p-values are shown.

\begin{tabular}{ccc}
\hline Elements and $\mathrm{pH}$ & $\mathrm{F}$ & $\mathrm{p}$ \\
\hline $\mathrm{Pb}$ & 8.1 & 0.000937 \\
$\mathrm{Zn}$ & 6.9 & 0.001990 \\
$\mathrm{Cu}$ & 24.4 & 0.000000 \\
$\mathrm{Cd}$ & 16.5 & 0.000010 \\
$\mathrm{Co}$ & 15.7 & 0.000014 \\
$\mathrm{~K}$ & 4.3 & 0.016576 \\
$\mathrm{~N}$ & 6.7 & 0.002432 \\
$\mathrm{P}$ & 23.1 & 0.000001 \\
$\mathrm{Mn}$ & 7.1 & 0.001836 \\
$\mathrm{Fe}$ & 4.1 & 0.018797 \\
$\mathrm{Mo}$ & 5.3 & 0.007261 \\
$\mathrm{Ca}$ & 33.4 & 0.000000 \\
$\mathrm{Mg}$ & 15.3 & 0.000017 \\
$\mathrm{Ni}$ & 1.7 & 0.202163 \\
$\mathrm{Cr}$ & 4.5 & 0.013995 \\
$\mathrm{pH}$ & 11.9 & 0.000091 \\
\hline
\end{tabular}

\section{Relationships between plant performance traits and chemical plant composition}

In the PCA of parameters measured in the plant samples, the three main extracted axes together explained $64 \%$ of the observed variation in parameters (Table 2, Fig. 3). The first factor, accounting for $32 \%$ of the variation, was mainly related to the essential mineral nutrient participating directly in the metabolism and indirectly supporting metabolism $(\mathrm{N}, \mathrm{P}, \mathrm{K}, \mathrm{Na}, \mathrm{Cu}$ and $\mathrm{Mn}$ in the negative side and $\mathrm{Ca}$ in the positive side). Moreover, the first factor correlated strongly to the NFP in the positive side. LS had a negative loading $(-0.56)$ in the first factor. The second factor, explaining $20 \%$ of the variation, was mainly related to the elements, which are directly required for enzyme reactions $(\mathrm{Mg}, \mathrm{Ni}, \mathrm{Co}$ and $\mathrm{Cr}$ ) in the negative side. Sulfur also had a negative loading in the second factor. Moreover, second factor correlated strongly to the TLA in the positive side. The third factor, explaining $12 \%$ of the variation, was mainly related to the reproduction (NSP and TWSP in the positive side). NFP also had a positive loading $(0.60)$ in the third factor (Fig. 3).

NFP was positively, strongly related to $\mathrm{Ca}$ and strongly, negatively related to $\mathrm{N}, \mathrm{Cu}, \mathrm{Na}, \mathrm{Mg}$, and $\mathrm{Ni}$ and weakly, negatively related to $\mathrm{P}, \mathrm{Mn}, \mathrm{K}, \mathrm{Cr}$, Co. NFP was negatively, strongly related to LS, but not to TLA. LS was negatively, strongly, related to $\mathrm{Ca}$ and NFP and strongly, positively related to $\mathrm{Ni}, \mathrm{Mg}$ and $\mathrm{Na}$ and weakly, positively related to $\mathrm{Cr}, \mathrm{Co}, \mathrm{N}, \mathrm{P}, \mathrm{Mn}, \mathrm{Cu}$ and $\mathrm{K}$. Thus, there was a trend in the data-set for populations exhibiting higher fruit production to also show higher plant calcium content and to show lower plant nitrogen, copper, sodium, magnesium and nickel concentrations and to also show a lower value of leaf length/width ratio and vice versa with the exception of nitrogen and copper concentrations. TLA was positively, strongly related to $\mathrm{K}$ and negatively, strongly related to $\mathrm{S}$ and weakly, negatively related to $\mathrm{Mg}, \mathrm{Ni}, \mathrm{Co}$ and $\mathrm{Cr}$. TLA was positively, strongly, related to PS. This indicates that in this data-set populations in which plant size and vegetative growth increased with plant potassium concentration were also those in which decreased plant sulphur concentration. NSP, TSWP and NFP were strongly related to each other (Fig. 3). This indicates that in this data-set po- pulations which began to increase in fruit production also increased in seed weight per plant with an increasing number of seeds per plant.

In the space defined by the three factors extracted by PCA, sites were arranged as follows: M1-M5 (marl soils) showed the highest content of $\mathrm{Ca}$ and lowest content of $\mathrm{Mg}, \mathrm{Ni}, \mathrm{Co}$ and $\mathrm{Cr}$ and highest NFP. S1-S4 (sandstone soils) showed the highest content of $\mathrm{Na}, \mathrm{N}, \mathrm{P}, \mathrm{Mn}, \mathrm{Cu}$ and $\mathrm{K}$ and the lowest $\mathrm{S}$ and high and the highest TLA and PS. G1-G3 (greenstone soils), L1-L7 (limestone soils), ME1 (melaphyre soil) and PM1-PM4 (polluted marl soils) and SER1 (serpentinite soil) showed high and the highest content $\mathrm{Mg}, \mathrm{Ni}, \mathrm{Co}$ and $\mathrm{Cr}$. TLA was lowest at L7 (limestone soil), ME1 (melaphyre soil) and at G3 (greenstone soil). NFP, and TSWP were lowest at SER1 (serpentinite soil) (Fig. 3).

\section{The relationship between plant parameters and soil characteristics}

Redundancy analysis (RDA) was executed to quantify the relationship between plant parameters and soil characteristics. The ordination produced by RDA was significant ( $\mathrm{F}=2.301, \mathrm{p}=0.0001)$, as well as the first canonical axis $(\mathrm{F}=3.414, \mathrm{p}=0.0294)$. The plant performance traits and elemental composition were significantly related to soil characteristics. The variation explained by the 16 soil variables (15 soil elements and soil $\mathrm{pH}$ ) was high $(79 \%)$. The forward selection of soil variables identified soil cobalt concentration, soil molybdenum concentration, soil nickel concentration, soil zinc concentration and soil calcium concentration as significantly influencing the ordination plant parameters. The variation explained by the selected soil variables was $55 \%$. Thus five soil variables appeared to be the main factors determining variation of performance traits and elemental composition of this species (Fig. 4).

\section{DISCUSSION}

\section{Soil}

Wide ranges of soil mineral element concentrations were observed for all elements across the study sites (Table 2). The soils derived from polluted marls and greenstones, marls, limestones and melaphire, sandstones, greenstone and serpentinite differ significantly between themselves in metal levels (except $\mathrm{Ni}$ ), nutrient availability and soil $\mathrm{pH}$ (Fig. 2, Table 3).

In this study, all soils showed low $\mathrm{P}, \mathrm{K}, \mathrm{S}$ and $\mathrm{Na}$ content, moderate $\mathrm{N}, \mathrm{Ca}$ and $\mathrm{Mg}$ content except the serpentinite and limestone sites. The serpentine soil had low Ca content, the limestone soils have high $\mathrm{Ca}$ and $\mathrm{Mg}$ content (Lityński and Jurkowska 1982). All soils except melaphyre soil contained elevated levels of $\mathrm{Cr}$ compared to the usual maximum values presented by Kabata-Pendias and Pendias (1999) and Kabata-Pendias (2001). The concentrations of soil $\mathrm{Ni}$ and $\mathrm{Zn}, \mathrm{Pb}, \mathrm{Cd}$ at the serpentinite site and polluted marl sites (respectively) exceeded the levels reported for typical uncontaminated soils (Lityński and Jurkowska 1982; Kabata-Pendias 2001). The concentrations of Fe, $\mathrm{Mn}, \mathrm{Cu}$ and $\mathrm{Mo}$ in all soils were in the usual range reported for normal soils (Kabata-Pendias and Pendias (1999) and Kabata-Pendias 2001). The main factor determining the $\mathrm{Cr}$ content of soil is the chemical composition of the 

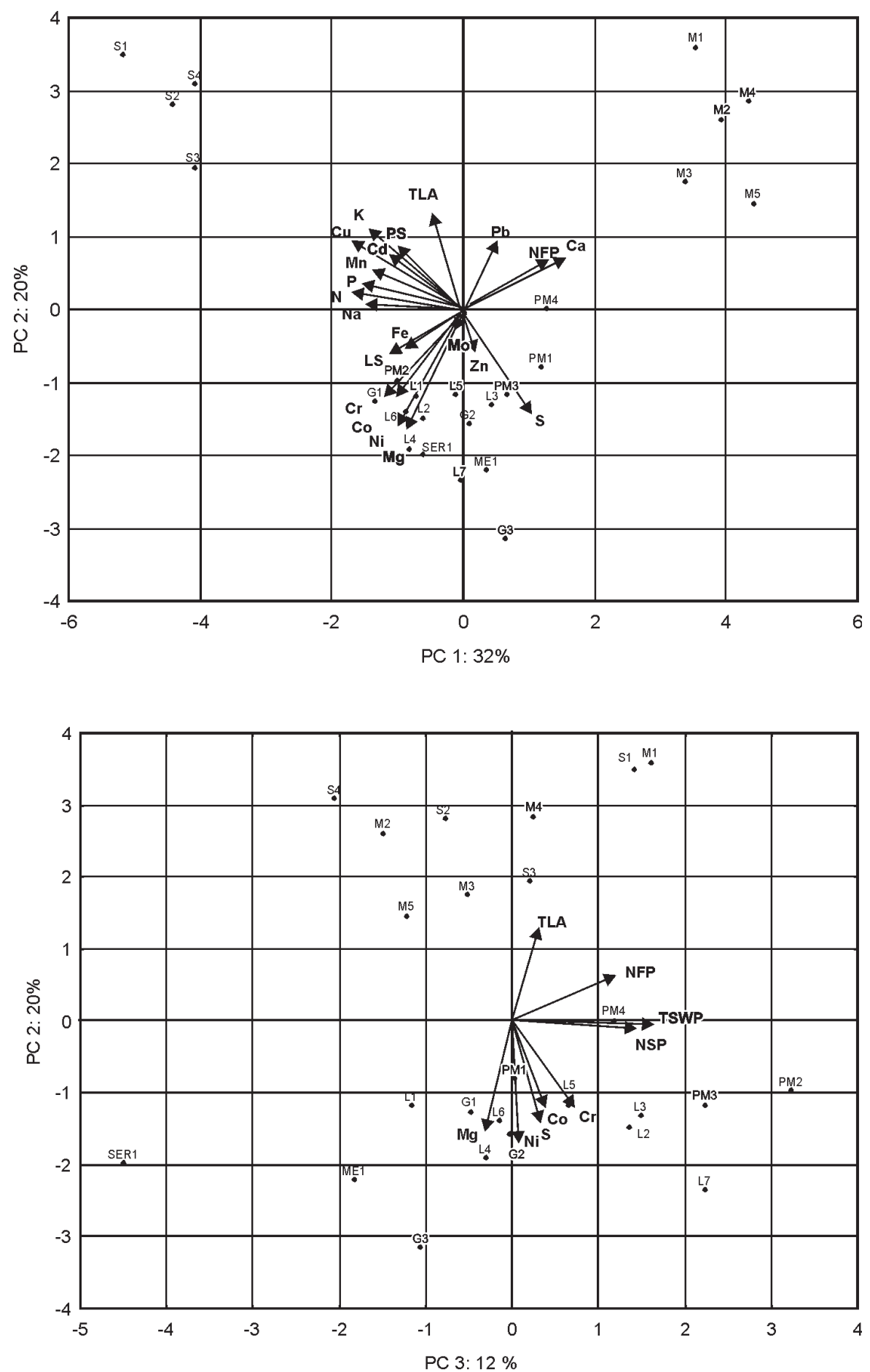

Fig. 3. Ordination of the 25 sites (dots) along three axes extracted by a PCA analysis based on twenty three plant variables measured at each site. For abbreviations see Tables 1-2.

parent rocks. The melaphyres, greenstones and serpentinites are included within basic mafic and ultramafic rocks (respectively) having rather a high content of $\mathrm{Cr}$ compared to sedimentary materials such as limestones, marls and sandstones having generally low content of $\mathrm{Cr}$ (KabataPendias 2001; Sterckeman et al. 2006). In soil derived from melaphyre, the parent material has a less pronounced influence on the soil $\mathrm{Cr}$ content than in soils derived from serpentine and greenstones. The elevated level of $\mathrm{Cr}$ in limestone, marl and sandstone soils point to a possible anthropogenic contamination of those sites with this element. The high content of $\mathrm{Ni}$ and $\mathrm{Zn}, \mathrm{Pb}, \mathrm{Cd}$ obtained in serpentine soil and polluted marl soils (respectively) are to be expected, considering the geochemistry of the serpentine site and characteristics of sites contaminated for about 150 years by dust from $\mathrm{Zn}-\mathrm{Pb}$ smelter. The soil of the serpentine site showed 5-10 times higher Ni level than those of other non-serpentine sites (Table 2). The soils of polluted marls sites showed 2-5 times higher $\mathrm{Zn}$ level, 2-3 times higher $\mathrm{Pb}$ level and 2-10 times higher Cd level than those of the other unpolluted sites (Table 2). This indicates that $C$. autumnale has the ability to grow in soil containing high concentrations of $\mathrm{Cr}, \mathrm{Ni}, \mathrm{Zn}, \mathrm{Pb}$ and $\mathrm{Cd}$. Plants have both constitutive (present in most phenotypes) and adaptive (present only in tolerant phenotypes) mechanisms for dealing with the perturbations of cell homeostasis that occur as result of elevated metal concentrations (Meharg 1994). Thus, it appears that $C$. autumnale may be constitutively 


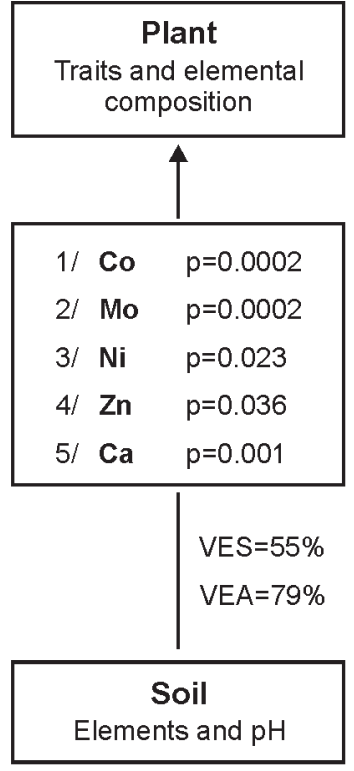

Fig. 4. Results of the investigation (by RDA) of the overall relationship between plant parameters (plant traits and chemical plant composition), and soil characteristics and main elements determining plant parameters for $C$. autumnale. Arrow shows overall significant $(\mathrm{alfa}=0.05)$ relationship between soil characteristics and plant parameters. Variables which explain a significant part of the relationship are indicated in the box along the arrow. Variance explained by all variables (VEA) and variance explained by the selected variables (VES) are given next to the arrow.

tolerant of a several metals such as $\mathrm{Cr}, \mathrm{Ni}, \mathrm{Zn}, \mathrm{Pb}$ and $\mathrm{Cd}$. In this study all soils exhibited high organic matter contents. Soils $\mathrm{pH}$ ranged from acidic to slightly acidic. All soils were classified as silt loam (medium-textured soils) according to Polish Standard PN-R-04033 (Bednarek et al. 2004). The soil texture and soil element concentrations (except $\mathrm{Ca}, \mathrm{Mg}, \mathrm{K}$ and $\mathrm{Pb}$ ) observed in this study were similar to those reported in studies from Eastern France that have investigated the influence of chemical characteristics of soil on mineral and alkaloid seed contents of $C$. autumnale (Poutaraud and Girardin 2005). The soils examined by Poutaraud and Girardin (2005) contained much higher concentrations of $\mathrm{Ca}, \mathrm{Mg}, \mathrm{K}$ and $\mathrm{Pb}$ and lower contents of organic matter than soils from these study sites. Soil $\mathrm{pH}$ values in the study sites were lower compared to the values presented by Poutaraud and Girardin (2005).

\section{Plant}

The present work demonstrated that there were also considerable variations in plant performance traits and element composition between populations (Table 2). In the examined plants, only the leaf length/width ratio at serpentine site exceeded the range presented by Persson (1999) for Balkan meadow saffrons. The number of fruits per plant and the total weight seed per plant in the examined plants were similar to those found in $C$. autumnale by Poutaraud and Girardin (2003) for natural sites and lower in those from cultivation sites (Poutaraud and Girardin 2006). Higher terrestrial plants reveal a variable and sometimes specific ability to absorb elements from soil (Brej and Fabiszewski 2003). In this study, only concentrations of $\mathrm{Cr}, \mathrm{Co}, \mathrm{Ni}$ in the leaves at all sites with the exception of marl sites and concentrations of $\mathrm{Fe}$ in the leaves at all sites except marl, serpentine sites and some limestone, greenstone sites (Table 2) exceeded the typical levels commonly encountered in most plants presented by Markert (1992), Kabata-Pendias and Pendias (1999), Kabata-Pendias (2001). Concentrations of $\mathrm{Cr}$ exceeded the typical level by two to four times, Co by two to five times and concentrations of $\mathrm{Ni}$ and Fe were slightly elevated to those reported by the abovementioned authors. However, the high (maximum) concentrations of $\mathrm{Cr}$ and $\mathrm{Co}$ and also $\mathrm{Ni}$ and $\mathrm{Fe}$ detected in the plant in this study do not approach those documented as excessive or toxic for plants (Kabata-Pendias 2001), but rather seem to be a property of $C$. autumnale. Similar concentrations of $\mathrm{Cr}, \mathrm{Co}$ and $\mathrm{Fe}$ to those found in this study of C. autumnale, were found by Freitas et al. (2004), Ghaderian et. al. (2006) in the leaves of most plant species, growing on serpentine soils. Due to unfavourable site conditions, many plants have developed the property of accumulating high concentrations of individual elements, frequently irrespective of whether these elements have a physiological benefit or not (Markert 1992). The beneficial effect of cobalt in $C$. autumnale on the regulation of alkaloid accumulation was detected by Poutaraud and Girardin (2005). In addition, the beneficial effects of this metal may also include retardation of leaf senescence, increased drought resistance in seeds and inhibition of ethylene biosynthesis (Palit et al. 1994). Moreover, there is also significant positive relationship between leaf and soil concentrations of Co, which means that meadow saffron may be a useful biomonitor for this metal (L. Mróz, unpublished data). With regard to $\mathrm{Cr}$, it has been shown that this element has a low mobility in the soil environment and should not lead to high contents in plants. However the rate of $\mathrm{Cr}$ uptake by plants is affected not only by soil $\mathrm{Cr}$ load, but also by complex interactions between numerous other soil properties as well as plant specific factors (Kabata-Pendias 2001). On the other hand, only a concentration of leaf $\mathrm{Mn}$ at all sites was approximate to the critical Mn deficiency level for most plants presented by Markert (1992), Kabata-Pendias and Pendias (1999), Kabata-Pendias (2001). The concentrations of $\mathrm{Mn}$ in $C$. autumnale analyzed in this work were very low and low but in the range reported for most other plant species found on serpentine soils from other parts of the world (Reeves et. al. 1999; Freitas et al. 2004; Ghaderian et. al. 2006).

\section{Plant-Soil}

This study shows that soil type has a significant effect on between-population variation in vegetative and reproductive performance and leaf macro- and micronutrient concentrations (Fig. 2 and 3). The leaf Ca content and number of fruits per plant (NFP) were correlated and were much higher in plants from metal (except $\mathrm{Cr}$ ) and nutrient-poor marl soils than in those from metal (except $\mathrm{Ni}$ in serpentine soil) and nutrient moderate rich soils derived from serpentinite, melaphire, greenstones, limestones and sandstones and in those from metal-rich and nutrient- poor polluted marl soils. These results point to that meadow saffron has a more effective uptake mechanism of $\mathrm{Ca}$ from marl soils. The correlation between Ca-NFP presented here is in agreement to data presented by Lityński and Jurkowska (1982), who reported that fruit production is closely associated with the leaf $\mathrm{Ca}$ content. Parallel to an increase in leaf $\mathrm{Ca}$ content and NFP there was a decrease in the leaf length/width ratio and leaf $\mathrm{N}, \mathrm{Cu}, \mathrm{Na}, \mathrm{Mg}$ and $\mathrm{Ni}$ concentrations (Fig. 3). 
These inter-element correlations are consistent with those mentioned by Kabata-Pendias and Pendias (1999) and Kabata-Pendias (2001) who reported that relations between Ca-trace elements are usually negative and those mentioned by Lityński and Jurkowska (1982), who reported that relations between Ca-macroelements may be either negative or positive. Plants may divide stored energy between production of leaves and fruits, and store energy obtained from phothosynthesis in corm for the following season (Falińska 2004). In the present study a trade-off between production of fruits and total leaf area (TLA) was not detected. However, a negative relation between production of fruits and shape of leaf was found. On the other hand meadow saffron plants tended to take up higher amounts of N, P, K, $\mathrm{Mn}, \mathrm{Cu}$ and $\mathrm{Na}$ and lower amounts of $\mathrm{S}$ and had much higher vegetative growth (TLA) in sandstone soils than those in serpentinite, melaphire, greenstone, marl and limestone soils. The results also show that the leaf $\mathrm{N}, \mathrm{P}, \mathrm{K}, \mathrm{Mn}, \mathrm{Cu}$ and $\mathrm{Na}$ concentrations and vegetative growth were positively correlated and leaf $\mathrm{S}$ concentration and vegetative growth negatively. Güsewell and Koerselman (2002) stated that both plant growth and leaf nutrient concentration tend to be positively correlated with nutrient supply when all other resources are sufficiently available. The results also show that the leaf $\mathrm{Co}, \mathrm{Ni}, \mathrm{Cr}, \mathrm{Mg}$ contents were correlated and much higher in plants from serpentinite, melaphyre, greenstones, polluted marl and limestone soils than in those from marl and sandstone soils. This indicates that bioavailability of these elements in the soil is relatively high. Overall, the pattern of variation in the number of fruits per plant (NFP) across the different soil type was the opposite of that for leaf $\mathrm{N}, \mathrm{Cu}, \mathrm{Na}, \mathrm{Ni}$ and $\mathrm{Mg}$ concentrations and total leaf area (TLA) was the opposite of leaf S concentration (Fig. 3). These results point to that those elements can potentially limit reproduction and vegetative growth. Redundancy analysis (RDA) enables identification of the soil variables that best explain the variance pattern of the plant response. The five soil variables such as soil $\mathrm{Co}, \mathrm{Mo}, \mathrm{Ca}$, $\mathrm{Ni}$ and $\mathrm{Zn}$ concentrations appeared to be the main factors determining the pattern variation of vegetative, reproductive and nutrient traits of $C$. autumnale (Fig. 4).

Results highlight the existence of substantial stores of ecological variation in vegetative growth and reproduction and element concentrations between populations. The populations exhibit several original characteristics. Study of the plastic and also genetic character of variation in traits and mineral composition, and its potential adaptive value, in plants deserves further attention.

\section{LITERATURE CITED}

BEDNAREK R., DZIADOWIEC H., POKOJSKA U., PRUSINKIEWICZ Z. 2004. Badania ekologiczno-gleboznawcze. PWN, Warszawa, 343 pp. (in Polish)

BERDOWSKI W. 1995. Flora rezerwatu "Łąka Sulistrowicka". Acta Uniw. Wratisl. 1667, 62: 113-124. (in Polish with English summary)

BREJ T., FABISZEWSKI J. 2003. Rośliny akumulujące metale ciężkie we florze Sudetów, Annales Silesiae 32: 155-163. (in Polish with English summary)

BROOKS R.R. 1987. Serpentine and its vegetation - a multidisciplinary approach. Dioscorides Press, Portland, OR, 454 pp.
CALLAWAY R.M., PENNINGS S., RICHARDS C.L. 2003. Phenotypic plasticity and interactions among plants. Ecology 84(5): 1115-1128.

CRAWLEY M.J. 1997. Life history and environment. In: Plant Ecology. Crawley M.J. (ed.), Blackwell Science, Oxford, pp. 73-131.

FALIŃSKA K. 2004. Ekologia roślin. PWN, Warszawa, 512 pp. (in Polish)

FRANKOVÁ L., CIBÍROVÁ K., BÓKA K., GAŠPARÍKOVÁ O., PŠENÁK M. 2004. The role of the roots in the life strategy of Colchicum autumnale. Biologia Bratislava 59, 13: 87-93.

FRANKOVÁ L., KOMJÁTHYOVÁ H., BÓKA K., GAŠPARÍKOVÁ O., PŠENÁK M. 2003, 2004. Biochemical and physiological aspects of developmental cycle of Colchicum autumnale L. Biol. Plantarum 47(4): 509-516.

FREITAS H., PRASAD M.N.V., PRATAS J. 2004. Analysis of serpentionophytes from nort-east of Portugal for trace metal accumulation - relevance to the management of mine environment. Chemosphere 54: 1625-1642.

GHADERIAN S.M., MOHTADI A., RAHIMINEJAD M.R., BAKER A.J.M. 2006. Nickel and other metal uptake and accumulation by species of Alyssum (Brassicaceae) from the ultramafics of Iran. Environ. Pollut. 145: 293-298.

GODET X. 1987. Biologie du colchique (Colchicum autumnale L.). Multiplication végétative par voie traditonelle et in vitro. Thèse, Clermont-Ferrand, $172 \mathrm{pp}$.

GÜSEWELL S., KOERSELMAN W. 2002. Variation in nitrogen and phosphorus concentrations of wetland plants. Perspect. Plant Ecol. 5/1: 37-61.

KABATA-PENDIAS A. 2001. Trace elements in soils and plants. CRC Press, Boca Raton, 413 pp.

KABATA-PENDIAS A., PENDIAS H. 1999. Biogeochemia pierwiastków śladowych. PWN, Warszawa, 398 pp. (in Polish)

KINDLMANN P., BALOUNOVÁ Z. 1999. Flowering regimes of terrestrial orchids: unpredictability or regularity? J. Veg. Sci. 10, 269-273.

KWIATKOWSKI P. 1998. Kamieniołomy wapienia w Górach Kaczawskich ostoją rzadkich i ginących gatunków flory naczyniowej Sudetów. Gór. Odkryw. 40(2-3): 156-163. (in Polish with English summary)

LEGENDRE P., LEGENDRE L. 1998. Numerical ecology. Elsevier Science B.V., Amsterdam, 853 pp.

LEPŠ J., ŠMILAUER P. 2005. Multivariate analysis of ecological data using CANOCO. Cambrige University Press, Cambrige, 269 pp.

LITYŃSKI T., JURKOWSKA H. 1982. Żyzność gleby i odżywianie się roślin. PWN, Warszawa, 643 pp. (in Polish)

MARKERT B. 1992. Presence and significance of naturally occurring chemical elements of the periodic system in the plant organism and consequences for future investigations on inorganic environmental chemistry in ecosystems. Vegetatio 103: $1-30$.

MEHARG A.A. 1994. Integrated tolerance mechanisms - constitutive and adaptative plant response to elevated metal concentration in the environment. Plant Cell Environ. 17: 989-993.

MRÓZ L. 2002. Cynk w glebie i zawartość kolchicyny w bulwach Colchicum autumnale L. w strefie oddziaływania huty "Oława" S.A. Zeszyty Naukowe Komitetu "Człowiek i Środowisko" PAN, 33: 325-329. (in Polish with English summary)

MRÓZ L. 2006. Variation in stage structure and fitness traits between road verge and meadow populations of Colchicum autumnale (Liliaceae): effects of habitat quality. Acta Soc. Bot. Pol. 75,1: 69-78.

PALIT S., SHARMA A., TALUKDER G. 1994. Effects of cobalt on plants. Bot. Rev. 60: 149-181.

PERSSON K. 1993. Reproductive strategies and evolution in Colchicum - Proceed. 5th OPTIMA Meeting, Istanbul, 8-15 September 1986, pp. 397-414. 
PERSSON K. 1999. New and revised species of Colchicum (Colchicaceae) from the Balkan Peninsula. Pl. Syst. Evol. 217: 55-80.

PIEKOŚ-MIRKOWA H., MIREK Z. 2003. Atlas roślin chronionych. Flora Polski. Multico, Warszawa, pp. 198-199. (in Polish)

POUTARAUD A., GIRARDIN P. 2003. Seed yield and components of alkaloid of meadow saffron (Colchicum autumnale) in natural grassland and under cultivation. Can. J. Plant Sci. 83: 23-29.

POUTARAUD A., GIRARDIN P. 2005. Influence of chemical characteristics of soil on mineral and alkaloid seed contents of Colchicum autumnale. Environ. Exp. Bot., 54: 101-108.

POUTARAUD A., GIRARDIN P. 2006. Agronomical and chemical variability of Colchicum autumnale accessions. Can. J. Plant Sci. 86,2: 547-555.

PROCTOR J. 1999. Toxins, nutrient shortages and droughts: the serpentine challenge. Trends Ecol. Evol. 14: 334-335.

RASKIN I., RYBNICKY D.M., KOMARNYTSKY S., ILIC N., POULEV A., BORISJUK N., BRINKER A., MORENO D.A, RIPOLL C., YAKOBY N., O'NEAL, CORNWELL T., PASTOR I., FRIDLENDER B. 2002. Plants and human health in the twenty - first century. Trends Biotechnol., 20, 12: 522-531.

REEVES R.D., BAKER A.J.M., BORHIDI A., BERAZAIN R. 1999. Nickel hyperaccumulation in the serpentinite flora of Cuba. Ann. Bot.-London 83: 29-38.
RUTKOWSKA B. 1984. Atlas roślin łąkowych i pastwiskowych. PWRiL, Warszawa, 367 pp. (in Polish)

STATSOFT Inc. 2005. Statistica (data analysis softwere system), version 7.1 StatSoft Inc., Tulsa, USA.

STERCKEMAN T., DOUAY F., BAIZE D., FOURRIER H., PROIX N., SCHVARTZ C. 2006. Trace elements in soils developed in sedimentary materials from Nothern France. Geoderma 136: 912-929.

TER BRAAK C.J.F., ŠMILAUER P. 2002. CANOCO reference manual and CanocoDraw for Windows User,s guide: Software for Canonical Community Ordination (version 4.5). Microcomputer Power (Ithaca, NY, USA), 500 pp.

TUTIN T.G., HEYWOOD V.H., BURGESS N.A., MORE D.M., VALENTINE D.H., WALTERS S.M., WEBB D.A. 1980. Flora Europea. Alismataceae to Orchidaceae (Monocotyledones). Cambridge University Press, Cambridge pp. 21-25.

WOHLGEMUTH T., GIGON A. 2003. Calcicole plant diversity in Switzerland may reflect a variety of habitat templets. Folia Geobot. 38: 443-452.

ZAR J.H. 1999. Biostatistical analysis. Prentice Hall, Upper Saddle River, New Jersey, 663 pp. 